\title{
COMPUTERISATION OF MODERN MEDICAL FACILITY ON THE EXAMPLE OF THE PRZYCHODNIA AKADEMICKA SP. Z O.O.
}

\author{
Krzysztof SKOWRON $^{1 *}$, Daria CHEBA ${ }^{2}$ \\ ${ }^{1}$ Silesian University of Technology, Faculty of Organization and Management, Institute of Management, \\ Administration and Logistics; krzysztof.skowron@polsl.pl, ORCID: 0000-0001-5458-6738 \\ ${ }^{2}$ Przychodnia Akademicka Sp. z o.o.; chebadaria@wp.pl \\ * Correspondence author
}

Purpose: The main aim of the article is to discuss an example of a selected medical facility compliance with formal and legal requirements concerning the obligation to computerise.

Design/methodology/approach: The scope is possible to achieve by using the research method in the form of a case study. The theoretical part contains considerations regarding the level of the development of e-government and e-health. It is also analyzed in terms of the legal framework and the documents forming electronic public services by the stages of their implementation. Furthermore, barriers and problems facing the process of e-government and e-health in Poland are also taken into account in this study.

Findings: On the basis of the conducted surveys, it was made the assessment of the every stage of computerisation of this entity, taking into account both those stages which were completed and those in progress.

Research limitations/implications: The conducted surveys were limited to a selected medical facility and may therefore be a prelude to more extensive analyses in this area.

Originality/value: The article contains a description of the specific action in the selected entity. In that regard, it represents a new local value. The results may be useful for researchers working on that subject and for the practitioners managing such entities.

Keywords: computerisation, e-government, e-health.

Category of the paper: Case study.

\section{Introduction}

Technical changes and the development of new IT tools, which took place in recent years, have affected the quality of life of almost every person - a citizen. At the current time, there is talk of the information age, electronic as well as digital. This is best characterised by the modern living conditions of the individual and society as a whole which are often referred 
to as the information society. The basic role in the development of this type of organised social group, as the name suggests, has been played by easily accessible information. The information society is one that has the technical, legal and economic instruments as well as the information knowledge that allows it to use these instruments (Karpiuk, and Chałubińska-Jentkiewicz, 2015). It is a feature of countries with a high level of technological development where information management requires the use of new techniques to collect, process, transmit and use information (Ganczar, 2009). Citizens using new information technologies in their daily lives will expect the country to cover every sphere of their lives. This increases the scope of the functions that the country must perform with regard to its citizens. This is crucial for the public interest purpose of implementing the idea of the information society (knowledge-based). The need for these transformations is not only of a technical nature, but also concerns changes in the social mentality. First of all, changes in the standards of relations between the individual and the public authority, the citizen and the country (Karpiuk, and Chałubińska-Jentkiewicz, 2015). In accordance with the development of new technologies, the administration should meet the requirements of the society and make it easier to handle official matters by electronic means. Computerisation is a process which is to serve the transformation of public administration and influence a new way of communication between the individual and public authorities. According to the dictionary definition, computerisation is the use of modern methods of information processing in the economy, technology etc. There are already a vast number of different definitions of this term in the literature (Dąbrowska, 2009; Sakowicz, 2008). While analysing the issue of computerisation it should be emphasised that it is, above all, a huge organisational and financial undertaking which must be well-planned. An essential stage in the process of computerisation is the arrangements at the level of the country's strategy (Karpiuk, and Chałubińska-Jentkiewicz, 2015). However, references to the European Union as a whole are necessary in order to give a good picture of the situation.

The European Union, not wishing to remain passive with regard to new technological developments has embarked on a series of legislative measures aimed at creating an "electronic Europe". The first step was the publication of the document "Europe and the Global Information Society. Recommendations to the European Council". The recommendations, "The Bangemann Report", were named after its author Martin Bangemann. The document set out the perspectives and directions of activities in the field of building information society (Ganczar, 2009). It took into account many aspects of the practical application of advanced communication and information procedures and was the first document to draw attention to the importance of these technologies throughout Europe (Musialik, 2012). The next step was the announcement of "eEurope - An information society for all" initiative in 1999 by then President of the European Commission. It was a kind of plan which was to lead to the creation of a joint action programme on electronic cooperation systems and the universalisation of Internet use the implementation of the objectives took place in several phases. In 2000, the so-called Lisbon Strategy was adopted, which aimed to make Europe the most dynamic and competitive economic region in 
the world by 2010. The implementation of the eEurope initiative has been identified as one of the most important elements of this strategy. The assumptions of the Lisbon Strategy included, among others:

- introduction of the Internet and multimedia in schools and their adaptation to educational needs, reducing prices for Internet access,

- accelerate the development of the legal framework necessary for the development of e-commerce,

- building and making high-speed Internet connections available to the scientific communities and students,

- popularisation of network services and electronic technologies in health care (e-health),

- ensuring effective tools for access to public sector information (e-government),

- promotion of teleworking.

It is now known that the objectives set out in the Lisbon Strategy have not been fully achieved by 2010 , which is why the Europe 2020 strategy is now being implemented, which is a continuation of the Lisbon Strategy and is aimed at smart, sustainable and socially inclusive growth with increased coordination at EU and national level.

\section{Introduction to "e-government"}

Public administration is an area which should benefit as much as possible from using new technical solutions. The total number of activities of government and local government administration authorities utilising new information and communication technologies is called e-government. (e-administration, electronic administration). According to the European Commission, e-government means a detailed redevelopment of administration conducted on the basis of information and communication technologies, aimed at opening the public sector to citizens, organisations and entrepreneurs focused on cooperation with it (Ganczar, 2009). The development of e-government is to be accompanied by the expansion of cooperation, including the connection of public administrations of the countries and inhabitants of Europe. Moreover, private entities will also be involved in these projects, which, by implementing technical solutions to provide services, will support the activities of the public administration and its authorities in the matter of implementation of these services in practice (Musialik, 2012). It is also worth mentioning that in the European Union's view, e-government is an element of a broader concept - the development of information society and knowledge-based economy. It is an integrated action with a view to creating a cheaper and more efficient administration, which in turn leads to better management of the country and lower administrative costs (Dąbrowska, 2009). 
In the literature, the expression e-government has been thoroughly analysed (Bal-Domańska, and Salus, 2010; Janowski, 2009; Adamski 2009). In the lexicon of administrative law, e-government is understood as a set of information and communication technologies connected with the organisational system in administration and new skills of administration employees, which is to improve the quality of administration and services provided by it (Tykwińska-Rutkowska, 2009). B. Kasprzyk has defined e-government as the use of ICT (Information and Communications Technology) by public sector to improve accessibility and streamline the delivery of public services (Kasprzyk, 2011). It should be stressed that the aim of e-government is to improve administrative services and not computerisation in itself. Although e-government is most often associated with the use of new technologies, it is not limited to this aspect (Nuzzo, 2015). The process of transforming 'traditional' administration into e-government is based on a redesign of internal administrative processes and the whole administrative structure, which will allow to meet the rapidly changing social needs (Błaszczyk-Domańska, 2013). The main reasons for the implementation of e-government are, first and foremost, time savings, a wide range of possibilities and a diverse range of services, convenience, overcoming geographical and time barriers and financial savings (Dąbrowska, 2009). The process of implementing the idea of e-government through appropriate application of new technologies and introduction of necessary legal regulations leads to transformation of administration into e-administration, which efficiently and effectively manages information and at the same time provides numerous benefits to the society (Luterek, 2010). Poland, as a member of the European Union, is obliged to implement the assumptions adopted by this international organisation. As it has been stressed before, in order to achieve the effectiveness of public administration in the area of matters related to computerisation, it is necessary to create appropriate legal framework.

\section{The process of computerisation of public administration in Poland}

The beginnings of implementation of the process of computerisation and development of e-government in Poland started in the year 2000 when the Sejm passed a resolution on building the foundations of information society in Poland (M.P. 2000 No. 22 item 448) [Official Gazette of the Republic of Poland]. In the same year, the Council of Ministers took a position on the resolution and adopted the programme "Objectives and directions of development of information society in Poland", developed together with the State Committee for Scientific Research and the Ministry of Communications. A year later, the law on access to public information (Dz.U. 2001, No. 112, item 1198) [Journal of Laws of the Republic of Poland] and electronic signature was passed (Dz.U. 2001, No. 130, item 1450). The first one introduced the idea of electronic administration into the Polish legal system and the obligation to publicise 
public information, including official documents, in an ICT publication - the Public Information Bulletin, while the second one was the basis for large-scale use of electronic communication in handling official matters. Another important document was the Act of July 18, 2002 on the provision of electronic services (Dz.U. 2002, No. 144, item 1204) and the Telecommunications Law passed in 2004 (Dz.U. 2004, No. 171, item 1800). The aim of this Act was primarily to promote equal and effective competition in the provision of telecommunications services, the development and use of modern telecommunications infrastructure as well as to provide users with maximum benefits in terms of diversity, price and quality of telecommunications services. The basic legal act sanctioning actions in state strategies concerning the process of computerisation was the Act on computerisation of activities of entities performing public tasks (Dz.U. 2005, No. 64, item 565) which imposed an obligation on public entities to provide and make available information by electronic means as part of the implementation of public tasks. The Act sets out the minimum IT standards that public entities must meet in order to be compatible. It also defines the principles of planning, standardisation, registration and control in the processes of computerisation and implementation of public tasks. The group of public entities that are obliged to apply the provisions of the Act includes (Dz.U. 2005, No. 64, item 565):

- government administration authorities, state control and law enforcement authorities, courts, prosecutor's offices as well as local government units and their bodies,

- budgetary units and local government budgetary establishments,

- special purpose funds,

- independent public health care institutions and other medical entities within the meaning of the provisions on medical activity,

- Social Insurance Institution [ZUS], Agricultural Social Insurance Fund [KRUS],

- National Health Fund,

- state or local government legal entities established on the grounds of separate acts in order to perform public tasks,

- universities,

- federations of entities in the tertiary education and research system,

- Polish Accreditation Committee,

- Council of Scientific Excellence.

In the above-mentioned provisions of the Act, the State Computerisation Plan was announced, which the Ministry of Scientific Research and Information Technology presented to the Council of Ministers for approval at the beginning of 2006 (Dz.U. 2006, No. 147, item 1064). The plan was revised as information and communication technologies developed (Dz.U. 2007, No. 61, item 415). The State Computerisation Plan assumed rationalisation of public administration expenditures in the area of computerisation and development of information society, creation of a modern and citizen-friendly state and technological neutrality 
of IT solutions used in the process of computerisation of administration (Dz.U. 2007, No. 61, item 415). In 2014, as a result of the amendment of the Act on Computerisation of the activities of entities performing public tasks (Dz.U. 2014, item 183), the State Computerisation Plan was replaced with the Integrated State Computerisation Programme, the objective of which is to create a coherent, logical and efficient state information system that would provide electronic services at the national and European levels in a manner that would be effective in terms of quality and costs (Ministry of Digital Affairs, 2018) [Website of the Republic of Poland, www.archiwum.mc.gov.pl]. Among the implemented ICT projects it is worth mentioning the Electronic Platform for Public Administration Services (ePUAP and ePUAP2), which was created for an easy and safe way of providing citizens, entrepreneurs and public institutions with basic services by electronic means. The ePUAP initiative was included in the State Computerisation Plan for 2007-2010 as one of the priority IT undertakings aimed at building e-government in Poland (Elektroniczna Platforma Usług Elektronicznych, 2018) [Electronic Platform for Public Administration Services, www.epuap.gov.pl]. The platform provides a catalogue of services offered within ePUAP. The services are divided thematically and the user can also view a list of all the procedures that ePUAP allows to perform via the Internet. In order to use the ePUAP platform, you need to create a trusted profile that allows you to confirm the identity of its holder in public services on the Internet (Ministry of Digital Affairs, 2018, www.obywatel.gov.pl). It also allows to sign letters in electronic form addressed to public entities. A signature confirmed by a trusted profile as well as a qualified electronic signature effectively replaces a handwritten signature in contacts with public entities (Ministry of Digital Affairs, 2018, www.gov.pl). On the other hand, the implementation of public services on the ePUAP platform is made possible by an electronic mailbox i.e. an electronic means of communication available to the public through which it is now possible to transfer information to a public entity. The Electronic Platform for Public Administration Services was launched on April 14, 2008. Further development of the ePUAP platform by expanding the range of services and creating IT links for individual systems enabled the launch of ePUAP2 in August 2015. All these activities are aimed at adjusting the work of public administration to the needs of the constantly developing information society (Ganczar, 2009). Servicing citizens through electronic services should save them time and avoid having to visit the place in person (except where seeing in person is required).

\section{Computerisation of the health care sector}

Besides the computerisation of the handling of official matters, a lot of attention has been paid to health care sector issues in recent years. They concern in particular the electronic management of individual medical records as well as the electronic access of medical 
professionals and patients to full medical records, including medical history, test results, medicines taken, referrals and sick leave issued (Karpiuk, and Chałubińska-Jentkiewicz, 2015). Access to these data is provided by the e-prescription, e-referral, e-order and e-sick leave programmes. The possibility of more convenient use of public health care would be to provide patients with such solutions as: online registration for a visit to a doctor (e-registration) or electronic health insurance card (Fiuk, 2017). The use of information and communication technologies in activities in the healthcare sector is referred to as e-health. Many, more or less elaborate definitions of the term have already been developed (Fuglewicz, and Szyjewski, 2009). However, as K. Wojsyk stresses, their common feature is the element of significant increase in the effectiveness of traditional health care systems due to the use of IT and ICT tools (Wojsyk, 2018).

The opportunities offered by new technologies in building an effective health care system have been recognised by the European Union which has set out the directions for their application in its documents. In 2004, the e-health plan was adopted ("making health care better for European citizens: An action plan for a European e-Health Area"), whose aim was to create a "European e-health area" (European Commission, 2018, www. ec.europa.eu). The Action Plan had two aims to achieve: maximising the use of new information and communication technologies in the healthcare sector and better integrating a range of e-health policies and actions. In response to the European call, the Centre for Health Information Systems [CSIOZ] which is a unit subordinate to the Ministry of Health in the field of computerisation, prepared the Healthcare Computerisation Programme (Ministry of Health, 2018, www2.mz.gov.pl). Projects implemented under this programme are aimed at comprehensive application of information and communication technologies in Polish health care sector.

The projects currently being carried out are:

- Project P1: Electronic Platform for Collection, Analysis and Sharing of Digital Resources on Medical Procedures,

- Project P2: Platform for Online Access to Services and Resources of Digital Medical Records for Entrepreneurs,

and awaiting launch:

- Project P3: Systems related to redevelopment, adaptation, maintenance and monitoring of records and other health care resources by public authorities, including state and local administration - Platform of Health Care Registers [PROZ], on the reserve list.

These projects will make accessible the basic functions of the e-health platform such as: support for Electronic Medical Records, e-prescriptions, e-registration, e-referral, online patient account, exchange of e-sick leave. They will enable a more effective patient involvement in the treatment process as well as cost reduction and comprehensive monitoring of the health services provided (Ministry of Health, 2018, www2.mz.gov.pl). In order to facilitate their implementation and precise assignment of tasks to particular entities and at the same time ensure coordination and control of activities, the Sejm of the Republic of Poland adopted the 
Act of April 28, 2011 on the information system in health care (Dz.U. 2011, No. 113, item 657 as amended). The Act introduces the concept of electronic medical documentation, according to which it consists of documents created in electronic form with a qualified electronic signature, a signature confirmed by the trusted profile of ePUAP or using the method of confirming the origin and integrity of data available in the ICT system made available free of charge by the Social Insurance Institution [ZUS]. The minister in charge of health specified the types of electronic documentation in his regulation (Dz.U. 2018, item 941). These are:

- information on the diagnosis of the disease, health problem or injury, the results of the tests carried out, the reason for refusal to admit the patient to hospital, the health services provided and any recommendations made

- information for the doctor referring the patient to a specialist outpatient clinic or hospital treatment concerning the diagnosis, treatment method, prognosis, prescribed drugs, dietary foods for particular nutritional uses and medical devices, during this period of their use and the manner of dosing as well as appointed follow-up visits,

- the information card from the hospital treatment.

The obligation to keep medical records in electronic form has been in place since January 1, 2019. The process of changes in the way medical records are kept has become a subject of more and more frequent mention in scientific literature (Pochopień, 2012; Perłakowska, and Szpor, 2013). What is more, practical studies have started to be developed where the authors address a number of problems concerning the process of computerisation of medical entities, thoroughly discussing the current legal status, obligations and tasks related to the implementation of new technologies (Gajda et al., 2013; Kamiński, and Rzymowski, 2011).

Another change that occurs in connection with the process of computerisation of the health care area is the e-prescription. It is a central IT system made available within the project of "Electronic Platform for Collection, Analysis and Sharing of Digital Medical Records". (System P1). The main aim of the available functionality of e-prescription is to facilitate the process of prescription implementation as well as to reduce errors, optimise time on the part of doctors and pharmacists and eliminate the problem of illegible and fake prescriptions. E-prescription is a digital version of the existing paper prescription. From January 1, 2020, prescriptions will have to be issued in electronic form (CSIOZ, 2018, www.csioz.gov.pl).

Similarly to e-prescriptions, e-referrals will be issued within the P1 System. In October 2018 the e-referral pilot started. Currently, the connection of medical entities to the system and tests are in progress. Referrals to services in the field of diagnostic tests, ambulatory specialist care and hospital treatment will be issued in the electronic form (Internet Patient Account, 2018, www.pacjent.gov.pl). The pilot will last until mid-2019. The electronic referral will be valid nationwide from January 1, 2021.

Revolutionary changes have also occurred in the issuance of sick leave. The amendments to the Act on cash benefits from social insurance in case of sickness and maternity (Dz.U. 1999, No. 60 , item 636 as amended) introduced a new way of issuing medical certificates in electronic 
form. From January 1, 2016, doctors can issue electronic medical certificates called e-ZLA. Sick leave on paper form [ZUS ZLA] could be issued until the end of November 2018. However, from December 1, 2018 doctors issue only e-sick leaves (ZUS, 2018, www.zus.pl). The doctor delivers the e-ZLA medical certificate (after signing it using the ZUS certificate, qualified electronic signature or signature confirmed by an electronically trusted profile to ZUS). Then, the Social Insurance Institution makes e-ZLA available to the payer of contributions (employer) on his profile on the ZUS Electronic Services Platform [PUE ZUS] no later than on the day following the day of receiving e-ZLA (without providing the statistical number of the illness). This information is also provided to the insured person (employee) who has the profile of the insured or the benefit recipient on the Social Insurance Institution [PUE ZUS]. From October 23, 2018 doctors will be able to authorise so-called medical assistants to issue e-sick leaves on their behalf. A medical assistant may be a person who performs a medical profession or activities auxiliary to the provision of health services. This person must have an account with PUE ZUS and be entered into the Register of Medical Assistants [RAM] (RAM, 2018, www.ram.rejestrymedyczne.csioz.gov.pl). This does not mean, however, that the medical assistant will decide to issue a sick leave. His or her role is limited to the performance of technical activities. It should be understood as a certificate being introduced into the electronic system and signed by itself. Issuing e-ZLA takes less time than issuing a paper sick leave and is automatically transferred to ZUS. Doctors no longer have to provide ZUS with sick leaves and keep a duplicate copy. There is also no need to obtain ZUS ZLA forms in ZUS offices. It is worth noting that medical e-sick leaves are also beneficial for the patient who does not have to provide the employer with a sick leave within seven days.

All electronic healthcare solutions will be integrated into the P1 System which will provide subsystems and applications that will improve healthcare planning and delivery processes. One of them will be the Internet Patient Account [IKP], introduced under the Act of July 20, 2018 on the amendment of the Act on information system in health care and some other acts (Dz.U. 2018, item 1515). A free online application that provides patients with access to information on prescriptions and referrals, medical records, doctor's and nurse's declarations and sick leave certificates. Access to it will be possible through a trusted profile which will guarantee the security of logging in and all data collected in the system.

\section{Characteristics of the selected medical facility}

The selected health care unit has its registered office in Gliwice. According to the legal status, the company operates under the name "Przychodnia Akademicka w Gliwicach Spółka z ograniczoną odpowiedzialnością" [limited liability company]. The company's registered office is in Gliwice. The company conducts business activities at 44-100 Gliwice, 5 Łużycka 
Street. The Company was entered on December 9, 2003 in the National Court Register which constitutes the register of entrepreneurs under number 0000182625 on the basis of a decision of the District Court in Gliwice, 10th Commercial Division. The Academic Clinic in the form of a company started its business activity on March 1, 2004 in the field of human health protection (PKD: 86.21.Z; 86.22.Z; 86.90.C; 86.90.A; 86.90.D; 86.90.E; 18.12.Z and 68.20.Z.) [Prepared on the basis of the Organisational Regulations of the Clinic of 8 January 2018]. The primary goal of the Academic Clinic is to:

- provision of outpatient preventive and therapeutic outpatient services such as basic health care to preserve, save, restore and improve health,

- providing outpatient specialist health care services (in the scope of: ophthalmology, otolaryngology, obstetrics and gynaecology, general surgery, trauma and orthopaedic surgery, neurology, cardiology),

- providing outpatient services such as psychiatric care and addiction treatment,

- carrying out tasks in the field of occupational medicine,

- providing services in the scope of medical diagnostics: medical and imaging analytics: $\mathrm{x}$-ray, ultrasonography, spirometry, hearing tests, electrocardiogram,

- to give an opinion on the health condition and temporary inability to work,

- promoting health education and health promotion.

The tasks performed by the Academic Clinic as part of its medical treatment activity consist in the delivery of health services in accordance with the principles of medical knowledge, generally applicable laws and other requirements in this respect while maintaining the appropriate quality of the services provided. On the basis of the above it can be concluded that the scope of activity of the presented health care unit is quite wide.

\subsection{Conditions for computerisation of a selected medical facility}

Initially, the company was located in Gliwice at 13 Moniuszki Street and leased a building with a total area of approx. $1,800 \mathrm{~m}^{2}$. The building dates back to the turn of the 19th and 20th centuries. There were over thirty physician's offices at the disposal of the staff and patients, but the building required numerous outlays on repairs and modernisations, which, among other things, reduced all activities in the field of computerisation to the implementation of only the basic requirements in this field. Therefore, in 2014, the then authorities of the Silesian University of Technology in Gliwice - the majority shareholder of the company - suggested changing the place of providing services and transferring the Clinic to the newly designed building at Łużycka Street in Gliwice.

The building is located on the ground floor of a 3-storey building. The clinic meets all the sanitary and epidemiological requirements and construction law requirements ensuring comfort and convenience for patients, as well as the inclusion of the clinic, currently located outside the 
academic campus, in its premises. The building and its surroundings have been fully adapted to the needs of the disabled and it is the most modern facility of its kind in the region.

The new building contains all the previous clinics and practices which were currently located on Moniuszki Street. In addition, patients will still have at their disposal the Analytical Laboratory and the following laboratories: x-ray, electrocardiogram, ultrasonography (including Doppler ultrasound), audiometry and spirometry. The plans also include the possibility of opening new clinics or practices.

The entire investment cost approximately PLN 16 million, and the final relocation of the company took place on August 16, 2016

\subsection{The company's computerisation schedule}

The relocation of providing health care services caused several significant changes in the functioning of the presented medical facility. First of all, the area and number of doctor's offices in the new premises significantly decreased. Secondly, due to the limited space available for the General X-ray Laboratory, it was necessary to consider digitalisation of the previously analogue X-ray apparatus. Thirdly, for similar reasons and also for formal reasons, it was necessary to discontinue the operation of one's own analytical laboratory in order to operate a collection point for testing material.

The above mentioned premises, especially the limited number of physician's offices, made the process of computerisation of the entire company easier to start. Its course and the costs incurred are presented in the table below.

Table 1.

The computerisation schedule of Przychodna Akademicka Sp. z o.o.

\begin{tabular}{|c|l|c|}
\hline \multicolumn{1}{|c|}{ Tate of purchase } & \multicolumn{1}{c|}{ specifics } & price \\
\hline \multicolumn{1}{|c|}{ Task 1 - server exchange } \\
\hline 15 September 2015 & Server + WinSvr + extended warranty & 12336,41 \\
\hline 15 September 2015 & WinSvr CAL 2012 5 User & 826,56 \\
\hline 25 November 2015 & computer + monitor & 2240,57 \\
\hline 27 November 2015 & APS Smart + installation & 1233,69 \\
\hline & \multicolumn{1}{|c}{ Task 2 - digitalisation of RTG apparatus } & $\mathbf{1 6 6 3 7 , 2 3}$ \\
\hline & FCR Imaging Plate Reader + computer + station & 106721,57 \\
\hline 1 February 2016 & MR PACS Server software & 12300,00 \\
\hline 15 February 2016 & Computers 3 pcs. & 600,00 \\
\hline 3 March 2016 & Server FS PAX + configuration & 2039,34 \\
\hline 18 May 2016 & \multicolumn{1}{c}{ Total: } & $\mathbf{1 2 1} \mathbf{6 6 0 , 9 1}$ \\
\hline
\end{tabular}


Cont. table 1.

\begin{tabular}{|c|c|c|}
\hline \multicolumn{3}{|c|}{ Task 3 - doctor's office equipment } \\
\hline 6 September 2016 & Keyboard 8 pcs. & 175,92 \\
\hline 6 September 2016 & Mouse 8 pcs. & 127,92 \\
\hline 8 September 2016 & Monitor 5 pcs. + Computer 5 pcs. + TP-Link & 5734,24 \\
\hline 14 September 2016 & Printer 2000D 10 pcs. & 2460,00 \\
\hline 19 September 2016 & Printer 2000D 1 pc. + monitor 4 pcs. & 845,99 \\
\hline 3 October 2016 & Mediqus license & 9840,00 \\
\hline 25 October 2017 & Windows 10 software & 445,00 \\
\hline 9 February 2018 & Monitor & 289,00 \\
\hline 13 February 2018 & Computers 2 pcs. & 1198,00 \\
\hline 7 March 2018 & Computers 2 pcs. & 1198,00 \\
\hline 27 March 2018 & Computers 2 pcs. & 1198,00 \\
\hline 11 April 2018 & Computers 2 pcs. & 1198,00 \\
\hline 20 April 2018 & Computer & 599,00 \\
\hline & Total: & 25309,07 \\
\hline \multicolumn{3}{|c|}{ Task 4 - increase data safety (GDPR) } \\
\hline 13 June 2018 & Server Synology & 1850,00 \\
\hline 17 September 2018 & FortiGate & 2348,07 \\
\hline 22 November 2018 & HDD 4TB 2 szt. & 1170,00 \\
\hline & Total: & 5368,07 \\
\hline \multicolumn{3}{|c|}{ Task 5 - registration desk modernisation } \\
\hline 24 November 2018 & Computer & 799,00 \\
\hline 26 November 2018 & Printer 2 pcs. & 468,00 \\
\hline 29 November 2018 & Computers 2 pcs. & 1498,00 \\
\hline 13 December 2018 & Photocopier & 1845,00 \\
\hline & Total: & 4610,00 \\
\hline & GRAND TOTAL & 173585,28 \\
\hline
\end{tabular}

Source: own elaboration based on the data of Przychodnia Akademicka Sp. z o.o.

In connection with the beginning of construction of the new facility and the current need to expand the existing server room, a decision to modernise it was already made in 2015 . The total investment cost amounted to PLN 16,637.23.

Then, due to the limited space available in the new facility for the General X-ray Laboratory, in 2016, even before moving to the new location, the digitalisation process of the $\mathrm{X}$-ray apparatus had started. The vast majority of the works were carried out in the new rooms, 
related to the exclusion of the X-ray Laboratory from operation in the old facility for over half a year and absorbed the amount of PLN 121660.91.

The next stage of the company's computerisation shortly after the new premises were opened was the equipping of all offices, laboratories and potential medical centres with computer hardware and software. The process was continuous due to the current needs and available funds. It lasted from September 2016 to April 2018 and the costs amounted to PLN 25,309.07.

Steps have been taken to modernise the relevant security measures on increasing the IT security and to be compliant with the General Data Protection Regulation (GDPR). The cost amounted to PLN 5,368.07.

The last stage closing the process of full computerisation of the company was the equipping and modernisation of the registration desks which amounted to PLN 4,610.00.

\section{Final conclusions}

The projects discussed in the introduction of this article will provide basic functions of the e-health platform such as: support for Electronic Medical Records, e-prescriptions, e-registration, e-referral, online patient account, exchange of e-sick leaves which will allow for more effective inclusion of the patient in the treatment process and for cost reduction and comprehensive monitoring of provided health services. In accordance with the Act of April 28, 2011 on the information system in health care (Dz. U. 2011 No. 113 item 657 as amended) all medical entities are obliged to continuously and systematically computerise their resources.

In the context of this case study the following conclusions can be drawn:

1. The medical facility in question systematically implements and uses the opportunities offered by new technologies in building an effective health care system. However, there are several aspects to this process. First of all, the financial aspect. The grand total of full computerisation of the facility amounted to PLN 173,585.28. This is a very large amount for a small company which explains the extent of the process over time. Secondly, a very large source of resistance in the implementation of particular IT systems were basically all the employees of the company with the exception of the management board and nurses whose implementation affected the least. The third aspect is the fact that the place where the services were provided changed. It was much easier to carry out computerisation in a new, smaller building, equipped with a full computer network, planned and designed to meet specific needs. If the same process were to take place in the old premises of the company, it would consume much more time and resources. 
2. The company benefited from the computerisation process in the form of legal benefits. The company meets all the formal requirements of the Act. The company meets all the requirements of the National Health Fund in the objective scope. The company benefited from the computerisation process in the form of time benefits. It allows now for faster time schedules, electronic circulation of documents (results, referrals, x-ray images etc.).

3. Computerisation has prepared the company for the possibility of launching further modules such as e-registration or a queueing system. Launching them is related only to the activation of individual elements not to the need to change the structure of the network/software/equipment.

4. Unfortunately, among many physicians there is still a great resistance against keeping electronic records. This is due both to the fact that some of them, due to their age, still have problems with computer use and the lack of a deadline for keeping medical records in digital form only.

\section{References}

1. Adamski, D. (2009). E-administracja. Prawne zagadnienia informatyzacji administracji. D. Szostek (Ed.). Wrocław: Wydawnictwo Presscom.

2. Bal-Domańska, B., and Salus, A. (2010). Wstęp do e-administracji: e-obieg dokumentów $w$ administracji publicznej z wykorzystaniem el-Dok-Systemu. Wrocław: Wydawnictwo Uniwersytetu Ekonomicznego.

3. Błaszczyk-Domańska, K. (2013). E-administracja: szanse i zagrożenia. T. Stanisławski, B. Przywora, Ł. Jurek (Eds.). Lublin: Wydawnictwo KUL.

4. Dąbrowska, A., Janoś-Kresło, M., and Wódkowski, A. (2009). E-ustugi a społeczeństwo informacyjne. Warszawa: Difin.

5. Fiuk, G. (2017). E-obywatel, E-sprawiedliwość, E-ustugi. K. Flaga-Gieruszyńska, J. Gołaczyński, D. Szostek (Eds.). Warszawa: Wydawnictwo C.H. Beck.

6. Fuglewicz, P., and Szyjewski Z. (2009). Informatyzacja ochrony zdrowia: wybrane zagadnienia. G. Bliźniuk (Ed.). Katowice: Wydawnictwo PTI - Odział Górnośląski.

7. Gajda, K. et al. (2013). Informatyzacja podmiotów leczniczych-jak przygotować gabinet na wejście dokumentacji elektronicznej? Kraków: Wydawnictwo FRDL Małopolski Instytut Samorządu Terytorialnego i Administracji.

8. Ganczar, M. (2009). Informatyzacja administracji publicznej: nowa jakość ustug publicznych dla obywateli i przedsiębiorców. Warszawa: Wydawnictwo CeDeWu.

9. http://archiwum.mc.gov.pl/konsultacje/program-zintegrowanej-informatyzacji-panstwa. 
10. http://www.zus.pl/elektroniczne-zwolnienia-lekarskie-e-zla-/e-zla-informacje-dlaasystentow-medycznych.

11. http://www.zus.pl/ezla.

12. http://www2.mz.gov.pl/wwwmz/index?mr=m17\&ms $=795 \& \mathrm{ml}=\mathrm{pl} \& \mathrm{mi}=795 \& \mathrm{mx}=0 \& \mathrm{ma}=$ 167.

13. https://ec.europa.eu/digital-single-market/en/news/e-health-making-healthcare-bettereuropean-citizens-action-plan-european-e-health-area.

14. https://epuap.gov.pl/wps/wcm/connect/epuap2/PL/Strefa+Klienta_Pomoc/O+projekcie.

15. https://obywatel.gov.pl/zaloz-profil-zaufany.

16. https://ram.rejestrymedyczne.csioz.gov.pl.

17. https://www.csioz.gov.pl/aktualnosci/szczegoly/e-skierowanie-kolejnafunkcjonalnoscsystemu-p1.

18. https://www.csioz.gov.pl/e-recepta.

19. https://www.gov.pl/web/cyfryzacja/program-zintegrowanej-informatyzacji-panstwa.

20. https://www.gov.pl/web/cyfryzacja/serwis-epuap.

21. https://www.gov.pl/web/zdrowie/internetowe-konto-pacjenta-szybki-i-latwy-dostep-dodanych-medycznych.

22. https://www.pacjent.gov.pl/pomoc/czym_jest_eskierowanie.

23. Janowski, J. (2009). Administracja elektroniczna. Warszawa: Wydawnictwo Municipium.

24. Kamiński, M., and Rzymowski, J. (2011). Informatyzacja podmiotów publicznych w pytaniach i odpowiedziach. Warszawa: Wydawnictwo Presscom.

25. Karpiuk, M., and Chałubińska-Jentkiewicz, K. (2015). Informacja i informatyzacja w administracji publicznej. Warszawa: Wydawnictwo Akademii Obrony Narodowej.

26. Kasprzyk, B. (2011). Aspekty funkcjonowania e-administracji dla jakości życia obywateli. In: Nierówności społeczne a wzrost gospodarczy. Społeczeństwo informacyjne-regionalne aspekty rozwoju. Rzeszów: Uniwersytet Rzeszowski. Katedra Teorii Ekonomii i Stosunków Międzynarodowych, 23.

27. Luterek, M. (2010). E-government: systemy informacji publicznej. Warszawa: Wydawnictwa Akademickie i Profesjonalne.

28. Musialik, T. (2012). E-administracja w Unii Europejskiej. Zeszyty Naukowe. Organizacja i Zarządzanie, 63a. Gliwice: Politechnika Śląska.

29. Nuzzo, B. (2015). E-administracja publiczna i (nie)bezpieczeństwo cyberprzestrzeni. M.K. Zwierżdżyński, M. Lakomy, K. Oświecimski (Eds.). Kraków: Wydawnictwo WAM.

30. Perłakowska, E., and Szpor, G. (2013). Dokumentacja elektroniczna w podmiotach publicznych. G. Szpor (Ed.). Warszawa: Wolters Kluwer.

31. Pochopień, P. (2012). Dokumentacja medyczna. Warszawa: Wolters Kluwer.

32. Rozporządzenie Ministra Zdrowia z dnia 8 maja 2018 r. w sprawie rodzajów elektronicznej dokumentacji medycznej, Dz.U. 2018, poz. 941. 
33. Rozporządzenie Rady Ministrów z dnia 1 sierpnia 2006 r. w sprawie Planu Informatyzacji Państwa na rok 2006, Dz.U. 2006, Nr 147, poz. 1064.

34. Rozporządzenie Rady Ministrów z dnia 28 marca 2007 r. w sprawie Planu Informatyzacji Państwa na lata 2007-2010, Dz.U. 2007, Nr 61, poz. 415.

35. Sakowicz, M. (2008). Administracja publiczna na progu XXI wieku: wyzwania i oczekiwania. J. Osiński (Ed.). Warszawa: Oficyna Wydawnicza SGH.

36. Tykwińska-Rutkowska, D. (2009). Leksykon prawa administracyjnego. 100 podstawowych pojęć. E. Bojanowski, K. Żukowski (Eds.). Warszawa: C.H. Beck.

37. Uchwała Sejmu Rzeczypospolitej z 14 lipca z 2000 r. w sprawie budowania podstaw społeczeństwa informacyjnego w Polsce, M.P. 2000, Nr 22, poz. 448.

38. Ustawa z dnia 10 maja 2018 r. o ochronie danych osobowych, Dz.U. 2018, poz. 1000.

39. Ustawa $z$ dnia 10 stycznia 2014 r. o zmianie ustawy o informatyzacji działalności podmiotów realizujących zadania publiczne oraz niektórych innych ustaw, Dz.U. 2014, poz. 183.

40. Ustawa z dnia 16 lipca 2004 r. Prawo telekomunikacyjne, Dz.U. 2004, Nr 171, poz. 1800 ze zm.

41. Ustawa z dnia 17 lutego 2005 r. o informatyzacji działalności podmiotów realizujących zadania publiczne, Dz.U. 2005, Nr 64, poz. 565 ze zm.

42. Ustawa z dnia 18 lipca 2002 r. o świadczeniu usług drogą elektroniczną, Dz.U. 2002, $\mathrm{Nr}$ 144, poz. 1204 ze zm.

43. Ustawa z dnia 18 września 2001 r. o podpisie elektronicznym, Dz.U. 2001, Nr 130, poz. $1450 \mathrm{ze}$ zm.

44. Ustawa z dnia 20 lipca 2018 r. o zmianie ustawy o systemie informacji w ochronie zdrowia oraz niektórych innych ustaw, Dz.U. 2018, poz. 1515.

45. Ustawa z dnia 25 czerwca 1999 r. o świadczeniach pieniężnych z ubezpieczenia społecznego w razie choroby i macierzyństwa, Dz.U. 1999, Nr 60, poz. 636 ze zm.

46. Ustawa z dnia 28 kwietnia 2011 r. o systemie informacji w ochronie zdrowia, Dz.U. 2011, $\mathrm{Nr} 113$, poz. 657 ze zm.

47. Ustawa z dnia 6 września 2001 r. o dostępie do informacji publicznej, Dz.U. 2001, Nr 112, poz. 1198 ze zm.

48. Wojsyk, K. (2018). E-zdrowie: wprowadzenie do informatyki w pieleggniarstwie. D. Kilańska, H. Grabowska, A. Gaworska-Krzemińska (Eds.). Warszawa: Wydawnictwo Lekarskie PZWL. 